\title{
Sequential and combined treatment of prolidase deficiency leg ulcers
}

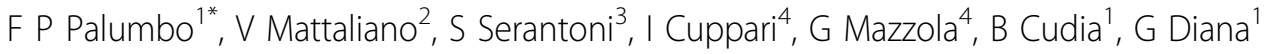 \\ From de Senectute: Age and Health Forum \\ Catanzaro, Italy. 5-7 December 2009
}

\section{Background}

The Authors report a case of chronic cutaneous lesions in a patient affected by prolidase deficiency, a rare disorder inherited through an autosomal recessive gene (50 cases reported).

The enzyme prolidase is widely distributed throughout the body and it is important in the recycling of proline and hydroxyproline. Among the clinical presentations, the most striking manifestation is the skin fragility with leg ulceration (see Table 1).

The deficiency of the enzyme prolidase is responsible for massive loss of proline in the urine which is estimated to be as high as $3 \mathrm{~g} /$ die. The diagnosis is ascertained by iminopeptiduria greater than $5 \mathrm{mmol} / 24 \mathrm{~h}$. A characteristic feature is absolute resistance to all forms of treatment including rejection of skin grafts.

\section{Materials and methods}

A 42 year-old woman affected by Prolidase Deficiency was observed because of the recurrence of leg ulcers (Figure 1). All clinical findings and laboratory data (iminopeptiduria $>6 \mathrm{mmol} / \mathrm{die}$ ) lead to a diagnosis. Administration of corticosteroids and of ointments were performed with no results. In 1998 an autologous skin transplant with the rejection of a skin graft. In 2007 administration of high dose corticosteroids with a partial regression of symptomatology. In October 2008 clinical feature suggested to cover all the lesion with hologous skin graft which was then partially rejected.

In January 2009 and all lesions were covered and during follow-up the use of autologous PLT-gel for 10 weeks was proposed. From the third application clinical data showed good results and after the tenth application all the lesions were treated with advanced devices. No

"U.O. Chirurgia Geriatrica, A.O.U. Policlinico Paolo Giaccone",Palermo, Italy
Table 1 Clinical signs of prolidase deficiency

\begin{tabular}{|c|c|c|c|}
\hline $\begin{array}{l}\text { Mental } \\
\text { retardation }\end{array}$ & Narrowed eyes & $\begin{array}{l}\text { Recurrent } \\
\text { infections }\end{array}$ & Splenomegaly \\
\hline Saddle nose & $\begin{array}{l}\text { Hypoplasia of the } \\
\text { jaws }\end{array}$ & Talipes equines & $\begin{array}{l}\text { Protuberant } \\
\text { abdomen }\end{array}$ \\
\hline Photosensitivity & Dry crusted lesions & Osteoporosis & \\
\hline Purpura & $\begin{array}{l}\text { Dry fissured } \\
\text { erythematous } \\
\text { Palms and soles }\end{array}$ & Corneal opacity & \\
\hline
\end{tabular}

signs of infection were present. The patient is now going into complete remission of skin lesions.

\section{Discussion}

Use of platelet gel is commonly accepted for the treatment of leg ulcers because it is rich in growth factors. Their presence could be a key to block the onset of a flogistic reaction to proline and hydroxyproline account in derma. All clinical investigations shows that after the PLT gel application there is not a rejection to homologous skin implants but an improvement in symptomatology and inability.

\section{Author details}

'U.O. Chirurgia Geriatrica, A.O.U. Policlinico Paolo Giaccone",Palermo, Italy. ${ }^{2}$ Angiologia, Clinica Barbantini, Lucca, Italy. ${ }^{3}$ Centro per la diagnosi e cura delle ulcere vascolari, Casa di cura "Villa Fiorita", Prato, Italy. ${ }^{4}$ U.O. di Medicina Trasfusionale - A.O.U. Policlinico, Palermo, Italy.

Published: 19 May 2010

\section{References}

1. Masood Q, Bath TA, Hassad I, Sameen F, Majid S: Prolidase Deficiency Indian J Dermatol. 2007, 52:00.

2. Ledoux P, Scriver CR, Hetchman P: Expression And Molecular Analysis of Mutations. In Prolidase Deficiency Am J Hum Genet 2007, 59:1-1.

doi:10.1186/1471-2318-10-S1-A20

Cite this article as: Palumbo et al:: Sequential and combined treatment of prolidase deficiency leg ulcers. BMC Geriatrics 2010 10(Suppl 1):A20. 

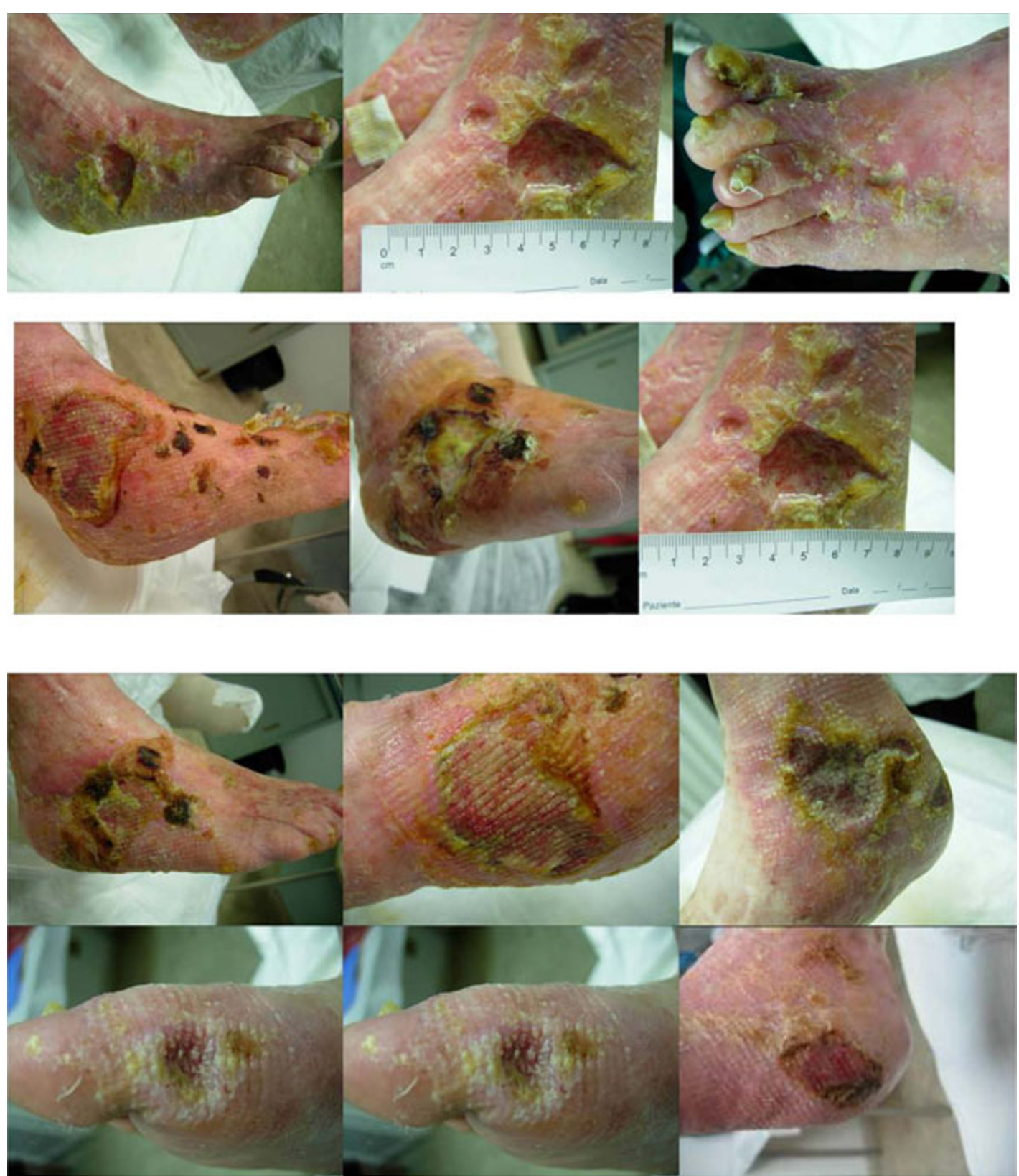

Figure 1 PD skin lesions before and after combined treatmnet 